\section{Uvanleg vakker bok}

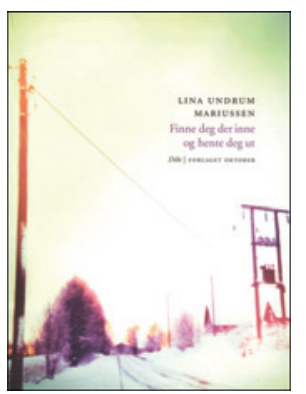

Lina Undrum Mariussen

Finne deg der inne og hente deg ut

Dikt. 62 s. Oslo: Forlaget Oktober, 2011

Pris NOK 199

ISBN 978-82-495-0841-9

det er noe i deg som snur seg

og føttene snur seg etter

du tenker at man kanskje kan komme hjem slik

bløt etter regnet og altfor sent

og se at noen har satt ut ei lykt på trappa

Dette er ei uvanleg bok. Uvanleg vakker og rørande. Om det mørke, hjelpelause og fortvilande rundt ein sjukdom som ikkje kan forståast eller behandlast. Sjukdomen har ikkje namn, vi kan undre oss på kva det medisinsk sett dreier seg om, men det er mindre viktig, og tittelen seier det meste: Finne deg der inne og hente deg ut.

Forteljarstemma er den eldste av to søstrer, og den yngre søstera er i ferd med å gli inn i ein tilstand av mørke, der både sinn og kropp visnar og veiknar, ord blir borte og søstera er i ferd med å drukne og døy ... Det er sorgfullt, det er fortvilande, det er vondt. Og kanskje det mest særeigne: det er vakkert rørande. Teksten rører ved kjenslene. Bileta er både diffuse og skarpe, emosjonelle og sanselege.

Boka er som eit samanhengande dikt, ei poetisk forteljing. Natur, sansar, kjensler, tankar og draumar. Håp og vonløyse.

hvordan skal jeg skrive denne historien om tusener av mennesker som legger seg ned uten forklaring

Ei bokmelding som dette kan ikkje skildre innhaldet eller historia i denne forteljinga; det er som om forteljinga veks utover kva ord kan formidle. Slik orda mellom søstrene blir både viktige og etter kvart uviktige, tomme. Då kan hendene formidle meir:

her sitter jeg og holder deg $\mathrm{i}$ hånda

og lar hendene snakke

jeg later som om hendene vet noe om deg

de sier de vet at det må gå over

jeg later som om hendene mine

er fulle av noe

som kan få deg til å lyse

hendene mine forstår noe

som jeg ennå ikke har forstått

......

de får det til å se enkelt ut

å holde andres gråt i hendene

de følger en oppskrift

jeg ikke kan huske å ha lært

hvordan kan jeg ha unngått å få med meg dette

som hendene har visst om bestandig

jeg legger hodet ditt fra meg og går ut

$i$ hagen, der jeg åpner ansiktet alene

Vakkert. Mystisk stundom, bileta er som poesi som må tolkast og få meining. Dette er ei bok for alle - for pårørande, venner og den sjuke, for alle hjelparar i alle yrke, også for legar trent til diagnostikk og behandling, som kan utvide sine røynsler.

Dette er ei bok eg kan tilrå og be folk lese.

\section{Så godt som sorgfrie kaker}

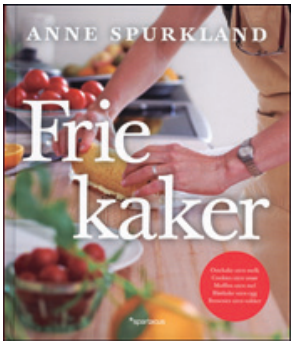

Anne Spurkland

Frie kaker

318 s, ill. Oslo: Spartacus forlag, 2011.

Pris NOK 349

ISBN 978-82-430-0623-2

Hva gjør du når tante Olga ikke tåler melk, vesle Iver ikke kan spise mel, farmor ikke liker nøtter, og alle skal på kaffebesøk samtidig? Anne Spurkland, professor ved Avdeling for anatomi, Universitetet i Oslo, vet råd! Den siste måneden har jeg bakt meg gjennom deler av Frie kaker - med personalet ved Finnsnes legekontor som velvillige og storfornøyde prøvekaniner.

Frie kaker inneholder over 100 illustrerte kakeoppskrifter, hver med en koselig bakgrunnshistorie. Boken er delt inn i fem deler: kaker uten melk, uten egg, uten mel, uten sukker og uten konvensjoner. Alle de klassiske kakesortene finnes i en variant fri for en eller flere av ingrediensene egg, mel, melk og sukker, som alle utgjør standard kakeingredienser. I tillegg inneholder seksjonen for konvensjonsfrie kaker noe mer uvanlige kaker, kaker som bidrar til å utvide mitt kakebegrep.

Det hele starter med en generell del om bakekjemi og innføring $i$ hva de ulike ingrediensene $i$ bakverket bidrar med, slik at man som kakebaker kan finne erstatninger når man er allergiker, har en med allergi i familien, får allergiske gjester eller regnet høljer ned og butikkturen ikke frister.

Boken er skrevet slik at det skal være mulig å finne de fleste ingrediensene i vanlige matvarebutikker. En svakhet er at noen få ingredienser er vanskelig å få tak i en mindre by uten internasjonale matvarebutikker, men stort sett finnes alternative anbefalinger, eller så kan man bruke seksjonen om bakekjemi for tips.

En del av kjøkkenutstyret som kreves, gjør også at kakene tidvis kan være utfordrende å lage på et kommunalt utstyrt turnuskjøkken. Noen av de svært alternative kakene forsvant mer langsomt fra lunsjrommet, men skal man dømme etter den gjennomsnittlige kakespisetakten og tilbakemeldinger fra enkeltmedarbeidere, vender Finnsnes legekontor tommelen opp for Anne Spurklands Frie kaker.

Kristin Viste

Finnsnes legesenter

Finnsnes 